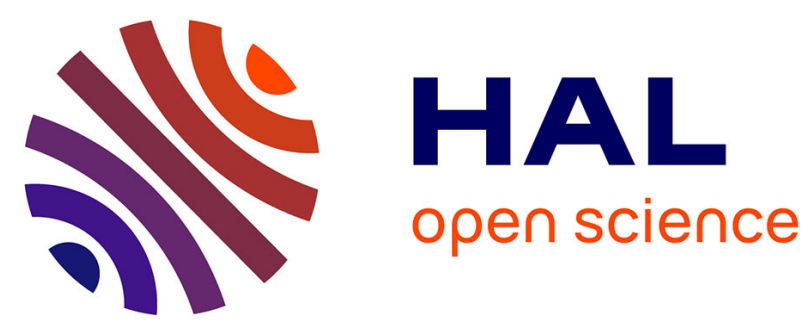

\title{
Parvovirus 4 in French in-patients: a study of haemodialysis and lung transplant cohorts
}

\author{
Mhammed Touinssi, Martine Reynaud-Gaubert, Carine Gomez, Pascal
}

Thomas, Bertrand Dussol, Yvon Berland, Agnes Basire, Christophe Picard, Jean François Cantaloube, Philippe de Micco, et al.

\section{To cite this version:}

Mhammed Touinssi, Martine Reynaud-Gaubert, Carine Gomez, Pascal Thomas, Bertrand Dussol, et al.. Parvovirus 4 in French in-patients: a study of haemodialysis and lung transplant cohorts. Journal of Medical Virology, 2011, 83 (4), pp.717-721. 10.1002/jmv.22003 . hal-00614692

\section{HAL Id: hal-00614692 \\ https://hal.science/hal-00614692}

Submitted on 15 Aug 2011

HAL is a multi-disciplinary open access archive for the deposit and dissemination of scientific research documents, whether they are published or not. The documents may come from teaching and research institutions in France or abroad, or from public or private research centers.
L'archive ouverte pluridisciplinaire HAL, est destinée au dépôt et à la diffusion de documents scientifiques de niveau recherche, publiés ou non, émanant des établissements d'enseignement et de recherche français ou étrangers, des laboratoires publics ou privés. 
Parvovirus 4 in French in-patients: a study of haemodialysis and lung transplant cohorts.

\begin{tabular}{|c|c|}
\hline Journal: & Journal of Medical Virology \\
\hline Manuscript ID: & JMV-10-2127.R1 \\
\hline Wiley - Manuscript type: & Research Article \\
\hline $\begin{array}{r}\text { Date Submitted by the } \\
\text { Author: }\end{array}$ & $31-$ Oct-2010 \\
\hline Complete List of Authors: & $\begin{array}{l}\text { Touinssi, Mhammed } \\
\text { Reynaud-Gaubert, Martine } \\
\text { Gomez, Carine } \\
\text { Thomas, Pascal } \\
\text { Dussol, Bertrand } \\
\text { Berland, Yvon } \\
\text { Basire, Agnes } \\
\text { Picard, Christophe } \\
\text { Cantaloube, Jean François } \\
\text { de Micco, Philippe } \\
\text { Biagini, Philippe; UMR CNRS } 6578 \text { Equipe « Emergence et co- } \\
\text { évolution virale », Etablissement Français du Sang Alpes- } \\
\text { Méditerranée et Université de la Méditerranée }\end{array}$ \\
\hline Keywords: & PARV4, Parvoviridae, hemodialysis, lung transplant, epidemiology \\
\hline
\end{tabular}

\section{SCHOLARONE ${ }^{\text {TM }}$ \\ Manuscripts}




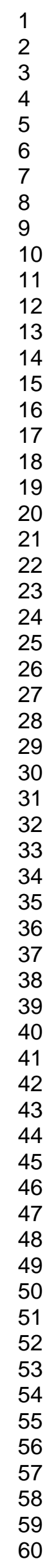

Fig. 1.

$297 \times 210 \mathrm{~mm}(200 \times 200$ DPI $)$ 
5 Mhammed Touinssi ${ }^{1}$, Martine Reynaud-Gaubert ${ }^{2}$, Carine Gomez ${ }^{2}$, Pascal Thomas $^{2}$,

6 Bertrand Dussol $^{3}$, Yvon Berland ${ }^{3}$, Agnes Basire ${ }^{4}$, Christophe Picard ${ }^{4}$, Jean-François

7 Cantaloube ${ }^{1}$, Philippe de Micco ${ }^{1}$, Philippe Biagini ${ }^{1 \star}$.

8

9

Running head: Parvovirus 4 in French in-patients.

\section{Parvovirus 4 in French in-patients:}

\section{A study of haemodialysis and lung transplant cohorts.}

1 Equipe «Emergence et co-évolution virale », Etablissement Français du Sang AlpesMéditerranée et Université de la Méditerranée, Marseille, France

${ }^{2}$ Service de Pneumologie, Pole Thoracique et Equipe de Transplantation Pulmonaire, CHU Nord, Marseille, France

${ }^{3}$ Centre de Néphrologie et de Transplantation Rénale, CHU Conception, Marseille, France

${ }^{4}$ Service Immunogénétique-HLA, Etablissement Français du Sang Alpes-Méditerranée, Marseille, France

* Correspondence: Dr. Philippe Biagini, UMR CNRS 6578 Equipe «Emergence et coévolution virale », Etablissement Français du Sang Alpes-Méditerranée et Université de la Méditerranée, 27 Bd. Jean Moulin, 13005 Marseille, France.

Tél. : 33.(0)4.91.32.45.53 / Fax : 33.(0)4.91.32.44.95

E-mail : philippe.biagini@efs.sante.fr / philippe.biagini@univmed.fr 


\section{ABSTRACT}

29 The epidemiology and the clinical implication of human parvovirus 4 (PARV4) in 30 human populations is still under evaluation. The distribution of PARV4 DNA was 31 determined in cohorts of French haemodialysis and lung transplant patients. Plasma 32 samples $(n=289)$ were tested for PARV4 by real-time PCR assay (ORF2), and 33 amplification products selected at random were sequenced. Analysis of available 34 serological and biological markers was also undertaken. Fifty-seven samples out of $35185(30.8 \%)$ were positive for PARV4 DNA in the cohort of haemodialysis patients. A 36 higher prevalence of the virus was identified in patients with markers of HBV 37 infection. PARV4 was also identified in 14 out of 104 samples (13.5\%) from lung 38 transplant recipients, with no clear-cut association with available clinical markers. 39 Point mutations located on the zone of real-time detection were identified for some 40 amplification products. This study describes the detection of PARV4 in the blood of 41 haemodialysis and lung transplanted patients with significant difference in prevalence 42 in these two cohorts. Further studies will be needed in order to understand better 43 both the potential implication in host health and the natural history of this virus. 
45

46 KEY WORDS: PARV4, Parvoviridae, haemodialysis, lung transplant, epidemiology, 47 genetic diversity.

48 
49

50

\section{INTRODUCTION}

Parvovirus 4 (PARV4) is a virus discovered recently belonging to the family Parvoviridae [Jones et al., 2005]. Identified initially in the blood of a patient harbouring acute viral syndrome, this virus had limited sequence homology with parvovirus B19 (<30\% aa similarity) despite a conserved genomic organization showing two large non-overlapping ORFs [Simmonds et al., 2008]. First studies revealed that the virus was present in the blood from intravenous drug users and individuals positive for $\mathrm{HCV}$ or $\mathrm{HIV}$ at prevalence ranging from $6 \%$ to $30 \%$, and in cohorts of kidney transplant patients as well [Biagini et al., 2008; Fryer et al., 2006; Fryer et al., 2007; Lurcharchaiwong et al., 2008; Vallerini et al., 2008]. PARV4 had been also identified in individuals without apparent pathology like blood donors (1\%24\%), and in blood products negative for parvovirus B19 DNA [Fryer et al., 2007; Lurcharchaiwong et al., 2008; Touinssi et al., 2010; Vallerini et al., 2008]. Genetic diversity of the virus is poorly known, but was extended recently to highly divergent animal variants identified in domestic (cow, pig) and wild (baboon, chimpanzee) species [Adlhoch et al., 2010; Lau et al., 2008; Sharp et al., 2010]. Interestingly, these studies demonstrated high prevalence values (up to $40 \%$ ) for these PARV4related animal viruses.

Another member of Parvoviridae family identified recently, human Bocavirus (HBoV) [Allander et al., 2005], had been more investigated and is suspected to be associated with wheezing and respiratory disease, mainly in young children [Brown, 2010].

Despite these advances, the natural history and the clinical role of these new viruses, and more particularly that of PARV4, remain unknown to a large extent. 
73 Aim of this study consisted in the evaluation of PARV4 DNA prevalence in two 74 different cohorts of haemodialysis patients and lung transplant recipients, combined 75 with the analysis of available serological and biological markers. An additional 76 investigation of HBoV DNA in lung transplant patients was also performed.

\section{MATERIALS AND METHODS}

80

\section{Clinical samples}

Two hundred and eighty-nine plasma samples originating from two cohorts of 83 in-patients from south-eastern France were analyzed retrospectively:

84 i) 185 haemodialysis patients (mean age 64 years; sex ratio 1.37 (men:women), 85 mean duration of dialysis $30 \pm 28$ months) from the Nephrology and Renal Transplant 86 Centre, Conception Hospital (Marseille) (date of sampling: 2007);

87 ii) 104 adult lung transplant recipients (mean age 42 years, sex ratio 0.73 ) 88 transplanted between October 2005 and August 2008, and followed at the Lung 89 Transplant Centre of the University Hospital of Marseille (date of sampling: from 90 June 2007 to December 2008); blood samples were not available before 91 transplantation.

92 Information relating to the presence of specific antibodies to HCV, HBV, HIV, and 93 HBs antigen in the plasma samples tested was collected. Of the 185 haemodialysis 94 patients, 22 tested positive for HCV, 75 for HBV, 4 for HIV, and 5 for HBsAg. Of the 95104 lung transplant recipients, only 2 tested positive for a serological marker of HCV. 96 Blood samples were collected in vacuum tubes (Vacutainer, SST, Becton 97 Dickinson, Meylan, France), centrifuged, and plasma aliquots were stored at $-80^{\circ} \mathrm{C}$ 
98 prior to DNA extraction. Total nucleic acids were extracted from $1 \mathrm{ml}$ of plasma by 99 using the MagNA Pure LC instrument (Roche Diagnostics, Meylan, France), as 100 described previously [Biagini et al., 2008; Touinssi et al., 2010].

\section{PARV4 PCR assay}

103 Samples were screened for the presence of PARV4 DNA by real-time PCR 104 (StepOne Plus, Applied Biosystems, Courtaboeuf, France) using a TaqMan detection 105 system located on the ORF2 of the viral genome. Primers used were PARV4Fwd (5'106 CTAAGGAAACTGTTGGTGATATTGCT-3') and PARV4Rev $\left(5^{\prime}-\right.$

107 GGCTCTCCTGCGGAATAAGC-3'), in combination with fluorogenic probe PARV4-N 108 (5'-FAM-TCCTACYGCCCSCTCCTCCTTCTT-TAMRA-3') [Touinssi et al., 2010].

109 Amplification reactions were performed using $5 \mu \mathrm{l}$ of extracted nucleic acids in 110 a $20 \mu \mathrm{l}$ reaction volume (TaqMan Fast Universal PCR kit, Applied Biosystems) 111 according to manufacturer's instructions. The amplification conditions were $95^{\circ} \mathrm{C}$ for 11220 seconds, followed by 50 cycles of $95^{\circ} \mathrm{C}$ for 1 second and $60^{\circ} \mathrm{C}$ for 20 seconds.

113 The sensitivity of the TaqMan assay was estimated at 10 copies of PARV4

114 DNA per reaction using dilutions of a synthetic template corresponding to the target 115 sequence (103 nt) [Biagini et al., 2008; Touinssi et al., 2010].

\section{HBoV PCR assay}

118 A real-time PCR assay for HBoV DNA located on the non-structural protein 119 (NP-1) gene was further applied to samples belonging to the lung transplant cohort. 120 Primers used were STBoNP-1f (5'-AGCATCGCTCCTACAAAAGAAAAG-3') and 121 STBoNP-1r (5'-TCTTCATCACTTGGTCTGAGGTCT-3'), in combination with 
122 fluorogenic probe STBoNP-1pr (5'-FAM-AGGCTCGGGCTCATATCATCAGGAACA-

123 TAMRA-3') [Tozer et al., 2009].

124 Amplification conditions were identical as those adopted for PARV4 detection.

125 The detection limit of the real-time PCR assay was 10 copies of HBoV DNA per 126 reaction [Tozer et al., 2009].

127

128 Sequence analysis

130

131

132 purified from agarose (Qiaquick Gel extraction kit, Qiagen, Courtaboeuf, France),

133 cloned into the pGEM-T Easy Vector System (Promega, Charbonnieres les Bains,

134 France) and further sequenced on both strands with M13 universal primers (BigDye

135 Terminator v1.1 Sequencing Kit, Applied Biosystems) on an ABI PRISM 3130XL 136 genetic analyzer (Applied Biosystem, Courtaboeuf, France).

137 Sequences were compared with those deposited in the GenBank database 138 using NCBI's online BLAST2 program (http://blast.ncbi.nlm.nih.gov/Blast.cgi).

\section{RESULTS}

142

143 Haemodialysis patients

Among the 185 samples tested, $30.8 \%(n=57)$ were positive for PARV4 DNA

145 using the real-time approach described. Analysis of serological markers revealed that 146 PARV4 DNA was detectable in $27.3 \%$ (6/22) and $38.7 \%(29 / 75)$ of patients positive 
147 for HCV and HBV, respectively. PARV4 DNA was further identified in $60 \%(3 / 5)$ of 148 patients positive for HBsAg, but not in any of the samples positive for HIV $(n=4)$. The

149 titre of PARV4 DNA in the positive samples was low (<500 copies/ml of plasma).

150 No specific correlation was found between PARV4 viraemia and duration of dialysis 151 or other available biological/clinical markers.

152

153 Lung transplant patients

154 PARV4 DNA was detected in $13.5 \%$ plasma samples (14/104), including one 155 of the two patients with HCV positive pretransplant viraemia who received 24 weeks 156 treatment with pegylated interferon alfa plus ribavirin, with a rapid virological 157 response and a negative viraemia before transplantation. A low titre of PARV4 DNA 158 (<500 copies/ml) was also noted. Patients with positive sera for PARV4 DNA were 159 transplanted for cystic fibrosis $(n=8)$, emphysema $(n=1)$, alpha 1 antitrypsin 160 deficiency $(n=1)$, pulmonary fibrosis $(n=3)$, sarcoidosis $(n=1)$.

161 Dating of positive samples ranged from 1 (day of transplant procedure) to 1097 days 162 after the allograft with a median of 206 days. No other serological marker was 163 identified in the cohort studied. No difference in clinical outcome and survival was 164 noted between recipients positive for PARV4 and those who were negative.

165 In order to analyse tentatively the time-course of infection in relation to patients 166 positive for PARV4 DNA, additional serial plasma samples obtained at \pm 6 months, 167 with respect to the date of initial positive detection, were investigated when available. 168 In each case ( $n=3$, on average), attempts to detect PARV4 DNA in these samples 169 remained unsuccessful.

170 Real-time PCR approach directed toward HBoV DNA gave no positive signal 171 in any of the samples tested. 
Genetic variability

Positive real-time PARV4 amplification products selected at random ( $\mathrm{n}=15$ and

$177 \mathrm{n}=14$ for haemodialysis patients and lung transplant recipients cohorts, respectively)

178 were confirmed by analysis on agarose gel electrophoresis, whereas negative

179 samples did not shown any amplification pattern. Amplification products confirmed

180 their PARV4 origin following cloning and sequencing. Most of them exhibited $100 \%$

181 nucleotide identity with the PARV4 prototype isolate (GenBank accession no.

182 AY622943) in this region, while three samples exhibited a point mutation (Fig. 1).

183 Absence of amplification was confirmed for each of the negative real-time 184 HBoV amplification products analyzed.

187 DISCUSSION

The real distribution and implication of PARV4 in humans is still under

190 investigation. Using the same molecular approach, the detection of PARV4 in about

$19120 \%$ of individuals without proven pathology like blood donors was reported recently,

192 suggesting a non-negligible dispersion of the virus in the population [Touinssi et al., 193 2010]. This study demonstrates that about $31 \%$ of a cohort of patients in 194 maintenance haemodialysis is infected with PARV4. Analysis of serological markers 195 characterising the cohort tends to confirm that the prevalence of the virus would be 196 higher in individuals showing, at least for HBV, hepatitis-related markers of infection. 
197 Such findings would be in accordance with the lower prevalence (13.5\%) identified 198 here in the cohort of lung transplanted patients, in which HCV, HBV and HIV markers 199 were hardly absent due to the preliminary selection of patients undergoing lung 200 allograft. However, the fact that this prevalence value was largely lower than that 201 identified in the normal population was unexpected and possibly due to undiscovered 202 aspects of PARV4 infection with respect to the immunosuppressive treatment of 203 patients.

HBoV DNA was not identified in the cohort of adult lung transplant recipients.

205 This would confirm its preferential implication in respiratory diseases of young 206 children, even if many aspects of its natural history remain to be clarified [Schildgen 207 et al., 2008].

208 A low titre of PARV4 viral particles $(<500$ copies $/ \mathrm{ml})$ was identified in all 209 positive samples identified in both cohorts. This is an agreement with previous 210 studies relating generally mild PARV4 levels in blood samples, although values 211 reaching up to $10^{6}$ copies $/ \mathrm{ml}$ were reported as well [Fryer et al., 2006; Fryer et al., 212 2007; Biagini et al., 2008; Touinssi et al., 2010]. In addition, the presence of 213 serological markers of HCV or HBV did not modify significantly the titre of viral 214 particles of the positive samples in the study. It is conceivable, however, that 215 fluctuations in viraemia would occur according to the immune status of the host, and 216 that additional serial samples tested negative here in the case of lung transplant 217 patients may represent periods of lowest replication of the virus, leading to 218 undetectable levels in blood.

219 It was also shown that point mutations may be identifiable in the short genomic 220 zone dedicated to PARV4 detection. This is in agreement with a recent study 221 demonstrating notable differences in the detection of the virus, even if two slightly 
222 different real-time approaches were used [Touinssi et al., 2010]. It is obvious that 223 detection strategies correlate directly with the progressive estimation of the real 224 genetic diversity of the virus. The fact that new, divergent, human and animal 225 variants were identified recently highlights the need to optimize detection methods 226 consistently.

227 This study demonstrates that haemodialysis and lung transplant patients could 228 be infected by PARV4, extending the spectrum of viral infections identifiable in these 229 cohorts [Alpers and Kowalewska, 2007; Fischer, 2008]. Many aspects characterizing 230 PARV4 are still largely unknown: both natural history and implication in host health, 231 along with its genetic diversity and real dispersion in human and animal species need 232 to be address in a near future. Interestingly, some aspects of this virus would be 233 close to those identified in another viral family identified thirteen years ago, 234 Anelloviridae [Biagini, 2009], which biology remains largely misunderstood. 


\section{REFERENCES}

238 Adlhoch C, Kaiser M, Ellerbrok H, Pauli G. 2010. High prevalence of porcine Hokovirus in German wild boar populations. Virol J 7:171.

254 Fryer JF, Kapoor A, Minor PD, Delwart E, Baylis SA. 2006. Novel parvovirus and $255 \quad$ related variant in human plasma. Emerg Infect Dis 12:151-154.

256 Fryer JF, Delwart E, Hecht FM, Bernardin F, Jones MS, Shah N, Baylis SA. 2007. 257 Frequent detection of the parvoviruses, PARV4 and PARV5, in plasma from $258 \quad$ blood donors and symptomatic individuals. Transfusion 47:1054-1061. 
259 Jones MS, Kapoor A, Lukashov VV, Simmonds P, Hecht F, Delwart E. 2005. New 260 DNA viruses identified in patients with acute viral infection syndrome. J Virol $261 \quad 79: 8230-8236$.

262 Lau SK, Woo PC, Tse H, Fu CT, Au WK, Chen XC, Tsoi HW, Tsang TH, Chan JS, 263 Tsang DN, Li KS, Tse CW, Ng TK, Tsang OT, Zheng BJ, Tam S, Chan KH, 264 Zhou B, Yuen KY. 2008. Identification of novel porcine and bovine parvoviruses 265 closely related to human parvovirus 4. J Gen Virol 89:1840-1848.

266 Lurcharchaiwong W, Chieochansin T, Payungporn S, Theamboonlers A, 267 Poovorawan Y. 2008. Parvovirus 4 (PARV4) in serum of intravenous drug users 268 and blood donors. Infection 36: 488-491.

269 Schildgen O, Müller A, Allander T, Mackay IM, Völz S, Kupfer B, Simon A. 2008. $270 \quad$ Human bocavirus: passenger or pathogen in acute respiratory tract infections? $271 \quad$ Clin Microbiol Rev 21:291-304.

272 Sharp CP, LeBreton M, Kantola K, Nana A, Diffo JL, Djoko CF, Tamoufe U, Kiyang 273 JA, Babila TG, Ngole EM, Pybus OG, Delwart E, Delaporte E, Peeters M, 274 Soderlund-Venermo M, Hedman K, Wolfe ND, Simmonds P. 2010. Widespread 275 infection of chimpanzees and gorillas with homologues of human parvoviruses 276 B19, PARV4 and human bocavirus in the wild. J Virol 84:10289-10296.

277 Simmonds P, Douglas J, Bestetti G, Longhi E, Antinori S, Parravicini C, Corbellino M. 278 2008. A third genotype of the human parvovirus PARV4 in sub-Saharan Africa. $279 \quad$ J Gen Virol 89:2299-2302.

280 Touinssi M, Brisbarre N, Picard C, Frassati C, Dussol B, Uch R, Gallian P, 281 Cantaloube JF, de Micco P, Biagini P. 2010. Parvovirus 4 in blood donors, $282 \quad$ France. Emerg Infect Dis 16:165-166. 
283 Tozer SJ, Lambert SB, Whiley DM, Bialasiewicz S, Lyon MJ, Nissen MD, Sloots TP. 284 2009. Detection of human bocavirus in respiratory, fecal, and blood samples by 285 real-time PCR. J Med Virol 81:488-493.

286 Vallerini D, Barozzi P, Quadrelli C, Bosco R, Potenza L, Riva G, Gregorini G, 287 Sandrini S, Tironi A, Montagnani G, De Palma M, Torelli G, Delwart E, Luppi M. 288 2008. Parvoviruses in blood donors and transplant patients, Italy. Emerg Infect 289 Dis $14: 185-186$. 


\section{LEGENDS}

291

292 Fig. 1. Alignment of PARV4 partial sequences showing location of point mutations in 293 the zone of real-time detection. HDx and LTx: sequences identified from 294 haemodialysis and lung transplant patients, respectively (GenBank accession nos 295 HM802325-27). Grey area : nucleotide sequence targeted by the real-time probe. 296 Lowercase letters : 5'/3' ends of real-time primers. 